\title{
KESENIAN DEBUS DI KABUPATEN SERANG
}

\section{Debus Performance Art in The Regency of Serang}

\author{
Oleh Euis Thresnawaty S \\ Balai Pelestarian Sejarah dan Nilai Tradisional Bandung \\ Jl. Cinambo No. 136 Ujungberung Bandung \\ Email: euisthresnawaty@yahoo.com
}

\begin{abstract}
Abstrak
Sejarah kesenian Debus di Kabupaten Serang dapat dikatakan masih sangat gelap karena tidak ada sumber-sumber tertulis yang bisa menjelaskan atau mengungkapkan periode Debus sebelum abad 19. Umumnya sumber yang ada hanya menjelaskan bahwa debus mulai ada pada abad ke-16 atau ke-17 pada masa kekuasaan Sultan Ageng Tirtayasa. Periode yang mulai terang adalah ketika masa mendekati awal kemerdekaan yaitu tahun 1938 ketika di Kabupaten Serang berdiri kelompok seni Debus di Kecamatan Walantaka, itu pun dengan sumber sumber yang terbatas. Hal menarik dari kesenian Debus ini adalah karena pada awalnya kesenian Debus mempunyai fungsi sebagai penyebaran agama Islam tetapi terjadi perubahan fungsi pada masa penjajahan Belanda yaitu pada masa pemerintahan Sultan Agung Tirtayasa seni ini digunakan untuk membangkitkan semangat perjuangan rakyat Banten melawan penjajah. Atas dasar itu maka dilakukan penelitian mengenai Sejarah Kesenian Debus di Kabupaten Serang dengan tujuan untuk dapat mengungkapkan latar belakang perjalanan sejarah serta dinamika perkembangannya. Adapun metode yang digunakan adalah metode sejarah. Saat ini permainan seni Debus dapat di katagorikan sebagai bentuk hiburan bagi masyarakat yang di dalamnya mengandung unsur zikir, silat, dan kekebalan.
\end{abstract}

Kata kunci: sejarah debus, kesenian debus

\begin{abstract}
It was not until the 19th century that written history of debus performing art came into light. The only thing we had was the information that debus began in 16th and 17th century during the reign of Sultan Ageng Tirtayasa. The light came to us saying that in 1938 there was a debus performing art group in Kecamatan (district) Walantaka, but the source is limited. Previously, debus functions as a means to disseminate Islam, but then it turned to be one used to fight Dutch colonialism in the reign of Sultan Ageng Tirtayasa. Today debus is a popular performing art involving zikir (rememberance of God in religous context), silat (traditional martial art), and kekebalan (make the body insensitive in order not to be conquered easily). The research aims to trace back the history of debus and its dynamic growth by conducting history methods.
\end{abstract}

Keywords: history of debus, debus performing art 


\section{A. PENDAHULUAN}

Kebudayaan merupakan hasil dari cipta, rasa, dan karsa manusia yang bisa melahirkan nilai berharga baik bagi dirinya maupun masyarakat. Oleh karenanya kebudayaan harus selalu dibina, dikembangkan, dilestarikan, dan disebarluaskan kepada masyarakat. Kebudayaan juga memiliki sifat yang selalu berkembang sehingga melahirkan kesenian-kesenian baru. Salah satu ciri jati diri bangsa yang masih ada adalah kesenian daerah yang harus terus dilestarikan keberadaannya.

Pertumbuhan dan perkembangan kesenian daerah tidak dapat dipisahkan dari warna dan ciri kehidupan masyarakat. Hampir setiap daerah di Indonesia mempunyai bentuk kesenian yang menggambarkan daerah setempat dan mempunyai latar belakang sejarah dan konteks sosial yang berbeda. Dalam seni masyarakat Banten pada umumnya tidak terlepas dari nafas keagamaan dan pengaruh agama Islam. Salah satu seni yang berkembang di Banten sampai saat ini adalah seni Debus.

Kesenian Debus adalah seni pertunjukan yang merupakan kombinasi dari seni tari, seni suara, dan seni olah batin yang bernuansa magis. Secara historis kesenian Debus Banten mulai dikenal pada abad ke17 pada masa pemerintahan Sultan Ageng Tirtayasa. Kesenian ini tumbuh dan berkembang bersamaan dengan berkembangnya agama Islam di Banten. Pada awalnya kesenian ini mempunyai fungsi sebagai penyebaran agama Islam. Akan tetapi pada masa penjajahan Belanda dan pada masa pemerintahan Sultan Agung Tirtayasa, seni ini digunakan untuk membangkitkan sema-ngat perjuangan rakyat Banten.

Dalam berbagai peristiwa di Banten yang panjang, rakyat Banten belum mengenal senjata modern seperti pistol dan senapan. Mereka hanya menggunakan senjata tradisional seperti keris, golok, dan bambu runcing. Untuk menghadapi berbagai peristiwa tersebut, para ulama dan tokoh agama memberi bekal yang mendorong keberanian rakyat dan pemuda Banten untuk bertempur di medan perang (Kartodirjo, 1984). Bekal yang diberikan bisa berupa doa-doa dan kemampuan kebal terhadap senjata tajam.

Penelitian ini mempunyai tujuan untuk mendapatkan gambaran tentang latar belakang sejarah kesenian Debus dengan ruang lingkup terbatas, yaitu Kabupaten Serang, Provinsi Banten dengan fokus utama pada sejarah kesenian Debus. Metode yang digunakan adalah metode sejarah dengan melalui empat tahapan, yaitu: tahapan heuristik atau proses pencarian dan pengumpulan sumber. Pada tahap heuristik ini digunakan teknik-teknik pengumpulan sumber sebagai berikut: studi kepustakaan, penelitian di lapangan, dan melakukan wawancara dengan tokoh-tokoh yang berperan atau mengetahui mengenai kesenian Debus. Kemudian dilakukan kritik sumber, baik kritik ekstern (tentang wujud sumber) atau kritik intern (tentang isi sumber) serta melakukan perbandingan data yang berasal dari berbagai sumber. Dilanjutkan dengan tahapan interpretasi, yaitu proses pemberian makna dan penafsiran secara jelas dan lengkap, dan akhirnya tahapan historiografi yaitu proses terakhir dalam penulisan sejarah yang berupa proses merangkaikan fakta-fakta yang berhasil dihimpun dalam sebuah kisah sejarah.

\section{B. HASIL DAN BAHASAN \\ 1. Gambaran Umum Wilayah}

Kabupaten Serang yang terletak di ujung Pulau Jawa bagian Barat adalah salah satu kabupaten dari 3 kabupaten dan 4 kota di wilayah Provinsi Banten yaitu Kabupaten Lebak, Kabupaten Pandeglang, Kabupaten Tangerang, Kota Cilegon, Kota Tangerang, Kota Tangerang Selatan, dan Kota Serang. Luas wilayahnya adalah 1.734,09 $\mathrm{km}^{2}$, terletak pada posisi koordinat antara 105 $7^{\prime}$ 105'22' Bujur Timur dan 5'50' - 6'21' Lintang Selatan. Secara administratif Kabupaten Serang terbagi atas 28 wilayah kecamatan, dan 308 desa. Kecamatan yang ada di wilayah Kabupaten Serang adalah: Kecamatan Pulo Ampel, Bojonegara, Kramatwatu, Padarincang, Mancak, Anyer, 
Cinangka, Waringin Kurung, Pabuaran, Gunung Sari, Baros, Ciomas, Petir, Tunjung Teja, Cikeusal, Pamarayan, Bandung, Jawilan, Kopo, Cikande, Kibin, Binuang, Kragilan, Carenang, Ciruas, Tirtayasa, Tanara, dan Pontang. Pada akhir tahun 2008, enam (6) kecamatan memilih memisahkan diri dari Kabupaten Serang dan mendeklarasikan terbentuknya Kota Serang, yaitu Kecamatan Curug, Serang, Cipocok, Taktakan, Kasemen dan Walantaka. Rencananya Pusat pemerintahan berada di Kecamatan Ciruas. Pada tanggal 17 Juli 2007 Kabupaten Serang dimekarkan menjadi Kota Serang dan Kabupaten Serang.

Secara geografis sebelah utara Kabupaten Serang berbatasan dengan Laut Jawa dan Kota Serang, di sebelah timur berbatasan dengan Kabupaten Tangerang, di sebelah selatan dengan Kabupaten Lebak dan Kabupaten Pandeglang, sedangkan di sebelah barat berbatasan dengan Kota Cilegon dan Selat Sunda. Letak geografis yang demikian merupakan keuntungan bagi Kabupaten Serang karena Kabupaten Serang menjadi pintu gerbang atau transit perhubungan darat antar Pulau Jawa dan Pulau Sumatera. Posisinya sangat strategis karena dilalui oleh jalan tol Merak-Jakarta, juga sebagai daerah alternatif dan penyangga (hinterland) ibu kota negara, karena dari Kota Jakarta hanya berjarak sekitar 70 kilometer.

Letak Kabupaten Serang yang sangat strategis membuat akses ke mana saja menjadi mudah. Lancarnya arus lalu lintas akan menunjang pembangunan dan perkembangan perekonomian suatu daerah. Bandara Internasional Soekarno-Hatta yang terletak di wilayah Kabupaten Tangerang memiliki jarak sangat dekat dengan Kabupaten Serang. Kabupaten Serang rencananya akan memiliki pelabuhan laut modern yang akan dibangun di Kecamatan Bojonegara seluas 455 hektar, sehingga akan dapat menunjang kegiatan perekonomian dengan akselerasi lebih cepat. Sekarang ini perhubungan antarpulau untuk penumpang dilakukan melalui Pelabuhan Merak di Kota Cilegon. Untuk perdagangan dan barang-barang di Pelabuhan Cigading dan Pelabuhan Karangantu, yaitu pelabuhan tua bersejarah yang pernah menjadi pelabuhan terbesar di kawasan Asia di masa lampau.

Iklim di wilayah Kabupaten Serang termasuk tropis dengan musim hujan antara November - April dan musim kemarau antara Mei - Oktober. Curah hujan rata-rata $3,92 \mathrm{~mm} /$ hari. Temperatur udara rata-rata berkisar antara $25,8^{\circ}$ Celsius $-27,6^{\circ}$ Celsius. Temperatur udara minimum $20,90^{\circ}$ Celsius dan maksimum $33,8^{\circ}$ Celsius. Tekanan udara dan kelembaban nisbi rata-rata 81,00 $\mathrm{mb} / \mathrm{bulan}$. Kecepatan arah angin rata-rata 2,80 knot, dengan arah terbanyak adalah dari barat.

Jumlah penduduk Kabupaten Serang pada tahun 2008 adalah 1.826.146 terdiri dari 948.753 laki-laki dan 877.393 perempuan. Pada tahun 2009 jumlah total penduduk Kabupaten Serang turun menjadi 1.345.557 terdiri 684.155 laki-laki, dan 661.402 perempuan. Sedangkan menurut data tahun 2010 jumlah penduduk mengalami kenaikan lagi menjadi 1.571.174 jiwa, dengan komposisi laki-laki dan perempuan berimbang, dengan laju populasi $2 \%$.

Tingkat pendidikan masyarakat Kabupaten Serang telah semakin baik. Di setiap kelurahan terdapat sedikitnya satu Sekolah Dasar (SD) dan fasilitas pendidikan terus berkembang dari tahun ke tahun. Kabupaten Serang memiliki 94 Sekolah Dasar (SD), 92 Sekolah Lanjutan Tingkat Pertama (SLTP), 35 Sekolah Menengah Umum, 4 Sekolah Menengah Kejuruan (SMK), 5 akademi, dan 7 Perguruan Tinggi (PT).

Latar belakang budaya yang kental dan sejarah heroik rakyatnya yang terkenal gagah berani melawan penjajah Belanda memberikan warisan warna khas keteguhan dan kegigihan masyarakat Serang dalam membangun wilayah Serang untuk kesejahteraan dan kemakmuran bersama. Semuanya tercermin pada lambang Kabupaten Serang yang bermottokan "Sepi Ing Pamrih, Rame Ing Gawe" yang berarti "Semangat Selalu Bekerja Keras, Tanpa Mengharap Imbalan".

\section{Sejarah Kesenian Debus}

Konsep kebudayaan menurut Geertz adalah suatu pola makna-makna yang diteruskan secara historis yang terwujud 
dalam simbol-simbol, atau sistem konsepkonsep yang diwariskan dalam bentukbentuk simbolis sehingga manusia berkomunikasi, melestarikan, dan mengembangkan pengetahuan mereka tentang kehidupan dan sikap-sikap terhadap kehidupan (Nasution, 1995: 27).

Untuk memahami dan menghayati totalitas cara hidup dan warisan sosial budaya yang diberikan oleh para pendahulu Banten sejak zaman kesultanan hingga sekarang bukanlah sebuah hal yang sederhana. Di sini dibutuhkan sebuah kemampuan untuk menggali kembali latar belakang sejarah sebuah kebiasaan yang diwariskan secara turun temurun. Upaya untuk menggali akar sejarah sebuah kesenian pun merupakan sesuatu hal yang sulit untuk diuraikan, karena telah berlangsung sangat lama. Kesenian khas Banten yang dahulu tumbuh subur bersamaan dengan berkembangnya agama Islam di Banten, kini telah mulai memudar bahkan di antaranya telah hampir punah ditelan zaman. Apabila berbicara mengenai kekhasan kesenian Banten, hanya ada satu yang dikenal ke seluruh Indonesia bahkan mancanegara, yaitu kesenian Debus.

Dalam berbagai literatur, kata Debus lebih difahami sebagai salah satu bentuk kesenian Banten yang merupakan produk dari masuknya Islam di daerah Banten yang terus berkembang pada masa kesultanan Banten. Debus juga dikenal sebagai suatu bentuk kesenian rakyat yang menonjolkan kekuatan dan ketahanan fisik. Dalam penampilannya, Debus memperlihatkan dan memperagakan kehebatan secara fisik yang ditunjukkan dengan gerakan-gerakan bela diri pencak silat, dipadukan dengan kehebatan ilmu kebatinan atau ilmu gaib (kekebalan). Di dalam Debus ada konsep permainan dan konsep kekebalan. Dengan demikian Debus memiliki dualisme makna yaitu sebagai bentuk permainan dan seni. Sistem yang terdapat dalam Debus memperlihatkan kelekatan dengan bentuk-bentuk permainan, apalagi dalam permainan Debus tidak tampak adanya suatu makna keindahan yang selalu dikandung dalam suatu karya seni. Debus selalu menampilkan suatu permainan yang menyeramkan tetapi mengagumkan, sesuatu yang sebenarnya ironis (Wawancara dengan Beni Kusnandar, 27 Maret 2011).

Debus memiliki makna yang dilandasi pada latar sejarah orang Banten yang sering berhadapan dengan peperangan atau pemberontakan melawan bangsa asing, yang tercermin dalam watak orang Banten yang keras dan berani. Adegan-adegan menakutkan dan mengerikan yang dipertontonkan oleh pemain Debus merupakan ekspresi perlawanan, pemberontakan, dan keberanian melawan ketidakadilan, kesewenang-wenangan serta penjajahan. Sesuai dengan konteks lahirnya kesenian Debus itu sendiri, sebagai salah satu bentuk perjuangan untuk mengusir penjajah Belanda. Kesenian ini merupakan peninggalan masa lampau, yaitu abad ke-17 ketika Kesultanan Banten tengah mengalami masa jayanya. Pada awalnya kesenian ini mempunyai fungsi sebagai sarana penyebaran agama Islam dan terus tumbuh dan berkembang bersamaan dengan berkembangnya agama Islam di Banten yang diperkenalkan oleh Sunan Gunung Jati, pendiri Kesultanan Cirebon, pada tahun 1520, dalam ekspedisi damainya bersamaan dengan penaklukan Sunda Kelapa.

Ada beberapa pendapat mengenai kata Debus ini, misalnya dalam Kamus Besar Bahasa Indonesia (2008: 162), kata debus atau dabus bermakna sebagai suatu permainan (pertunjukan) kekebalan terhadap senjata tajam atau api dengan menyiksa diri. Menurut Isman Pratama Nasution dalam tesisnya "Debus, Islam dan Kiai" (1995: 38), istilah kata Debus secara garis besar memunculkan dua pendapat. Pendapat pertama menyatakan bahwa asal kata debus dari bahasa Sunda. Menurut Tb. A. Sastrasuganda, pensiunan Kepala Seksi Kebudayaan Departemen Pendidikan dan Kebudayaan, Kabupaten Serang, kata Debus berasal dari kata "tembus". Hal ini menurutnya dikaitkan dengan alat yang digunakan untuk bermain adalah alat yang tajam dan bila ditusukkan ke dalam tubuh bisa tembus karena tajamnya alat tersebut. Pendapat kedua mengatakan bahwa kata Debus berasal dari 
bahasa Arab, yaitu dabbus yang berarti "sepotong besi yang tajam". Sepotong besi itu menjadi alat inti pada permainan ini, panjangnya $40 \mathrm{~cm}$ dengan ujung yang runcing. Ada pula yang mengatakan bahwa kata Debus berasal dari bahasa Persia, yaitu dabus yang berarti tusukan. Pendapat ini didasari oleh pandangan bahwa seni Debus sampai ke Banten melalui Aceh dari Persia.

Mohamad Ali Fadilah dalam makalahnya, "Dari Magic Performance ke Tourist Attraction" (http//wwwsahabat silat.com), menyatakan bahwa istilah Debus tidak ada kaitannya dengan kata 'tembus', tetapi diadopsi dari bahasa Arab, yaitu dabbus. Menurutnya setelah cukup banyak kajian tentang Debus seharusnya tidak perlu lagi membuat kekeliruan dalam merumuskan terminologi Debus, karena kesalahan menjelaskan istilah dapat menimbulkan persepsi yang salah pula tentang Debus. Penamaan dabbus, yang kemudian berubah menjadi Debus atau gedebus dalam tradisi lisan Banten, lebih mengacu pada elemen utama, yaitu sejenis 'demonstrasi' menancapkan besi berkepala kayu dengan bantuan alat pukul (gada). Kalau kemudian digunakan elemen besi lain seperti golok, pisau atau tusukan besi berukuran kecil, atraksi itu merupakan kreasi baru. Pada umumnya pertunjukan Debus selalu dilihat sebagai tiga aksi, pertama, aksi melagukan beluk sebagai formula zikir, kedua melakukan tarian mistis, dan ketiga, aksi menusuk, membacok, dan mengiris bagian tubuh manusia dengan benda tajam baik dengan alat Debus, golok atau pun pisau.

Dari bukti yang ditemukan bahwa seni ini tumbuh dan berkembang di pesisir pantai dan daerah-daerah tempat penyebaran agama Islam seperti Aceh, Bugis Makasar, Sumatra Barat, dan Banten. Tetapi ternyata jenis kesenian ini di setiap daerah tempatnya berkembang memiliki perbedaan-perbedaan baik istilah, teknik penyajian, musik pengiring, dan model penyajiannya. Kemungkinan besar perbedaan itu dipengaruhi oleh adat istiadat masing-masing daerah.
Di Aceh permainan jenis ini dinamai Rapa' $i$, disebut juga daboih atau meudaboih, dan jarum tusuknya disebut daboih. Di Sumatra Barat permainan jenis ini disebut badabuih atau dabuih, yang berarti jarum tusuk. Sementara di daerah Bugis, Makasar jenis permainan ini dikenal dengan nama daboso (Purnama, 1998: 40).

Pada masa Panembahan Maulana Hasanuddin pada abad ke-16 (15321570), Debus digunakan sebagai seni untuk memikat masyarakat Banten yang masih memeluk agama Hindu dan Budha dalam rangka penyebaran agama Islam. Kemudian, ketika kekuasaan Banten dipegang oleh Sultan Ageng Tirtayasa pada abad ke-17 (1651-1682), Debus difokuskan sebagai alat untuk membangkitkan semangat para pejuang dalam melawan penjajah Belanda. Raja Banten ke-5 yang gemar kesenian dan kebatinan ini telah berhasil meningkatkan semangat tempur angkatan perangnya melalui permainan Debus dan silat.

Wilayah Banten dalam kurun waktu yang lama merupakan wilayah yang tidak pernah lepas dari proses yang diwarnai dengan ketegangan dan konflik sebagai akibat bertemunya dua atau bahkan lebih pihak yang bertentangan untuk kepentingan yang berbeda. Kedatangan Islam dan bangsa asing ke Banten menimbulkan interaksi yang mengakibatkan timbulnya ketegangan antara penduduk setempat dengan pendatang. Ketika itu rakyat Banten belum banyak mengenal senjata modern, seperti pistol dan senapan. Mereka hanya menggunakan senjata tradisional seperti keris, golok, dan bambu runcing, sehingga kekuatan sangat tidak berimbang karena Belanda mempunyai senjata yang sangat lengkap dan canggih pada saat itu. Karenanya, para ulama dan tokoh agama berupaya dengan memberi 'bekal' yang bisa menumbuhkan keberanian rakyat dan pemuda Banten untuk melawan penjajah dan selalu siap untuk bertempur. Bekal yang diberikan adalah berupa doadoa, semangat juang, dan kemampuan kebal terhadap senjata tajam. Satu-satunya senjata yang dimiliki oleh rakyat Banten sebagai warisan leluhur adalah seni beladiri Debus 
yang kini lebih dikenal sebagai suatu kesenian tradisional. Mereka melakukan perlawanan secara gerilya.

Berbicara mengenai Debus tidak bisa dilepaskan dari keberadaan agama Islam di Indonesia dan aliran-aliran tarekatnya. Agama Islam masuk ke Indonesia sekitar abad ke-7 Masehi sampai abad ke-13 Masehi, ditandai dengan berdirinya Kerajaan Samudra Pasai di Aceh. Islam masuk ke Indonesia melalui berbagai jalur, di antaranya melalui perdagangan dan kedatangan para sufi. Perkembangan Islam yang dibawa para sufi ini mendapat perhatian besar masyarakat Indonesia, karena pada umumnya para sufi ini memiliki kelebihankelebihan yang tidak dimiliki manusia biasa (Nasution, 1995: 50).

Para sufi menjadi penggerak utama munculnya Islam yang dekat dengan hal-hal yang bersifat di luar nalar manusia biasa atau gaib. Mereka membentuk kelompokkelompok atau perkumpulan-perkumpulan tarekat yang dimaksudkan untuk membina umat dari segi akidah dan hal-hal yang berbau mistis. Munculnya sejumlah tarekat memperlihatkan kecenderungan ini, yaitu cukup kental dengan dunia mistis. Di antara sejumlah tarekat yang muncul di Indonesia adalah tarekat Naqsabandiyah, Qadiriyah, dan tarekat Rifa'iyah. Kehadiran kedua kelompok tarekat ini dikaitkan dengan munculnya Debus di Indonesia (Nasution, 1995: 2).

Debus pada dasarnya terbagi atas 2 (dua) aliran, yaitu Debus Tarekat dan Debus Ilmu. Debus Ilmu merupakan kemampuan/kekuatan yang diperoleh di luar jalur tarekat. Debus ini dapat berupa tirakat dan mantra-mantra dalam bahasa daerah (kejawen). Debus Tarekat merupakan kemampuan/kekuatan batin yang diperoleh melalui amalan suatu ajaran tarekat, biasanya pelaku Debus Tarekat dalam atraksinya selalu menyertakan lafadz kalimat Toyyibah, seperti Lailahailallah atau cukup Allah saja seperti amalannya para Sufi.

Seperti telah diuraikan di atas, seni tradisional Debus diduga disebarkan melalui ajaran tarekat Islam. Untuk mengetahui asal usul seni permainan ini maka akan ditelusuri terlebih dahulu apa sebenarnya tarekat itu. Dalam agama Islam dikenal tingkatantingkatan, yaitu syariat, tarekat, ma'rifat, dan hakikat. Umat Islam yang bisa melaksanakan semua rukun Islam dikatakan baru bisa melaksanakan ajaran syariat Islam. Untuk yang ingin meningkatkan lagi dari tingkatan syariat adalah tingkatan tarekat, dan seterusnya hingga tingkatan hakikat yang telah dicapai oleh para sufi (Atjeh, 1993: 58).

Tarekat adalah pengamalan syariat yaitu hukum-hukum yang telah diturunkan Allah kepada Nabi Muhammad SAW yang telah ditetapkan oleh ulama melalui sumber al-Quran dan sunnah. Kata tarekat dapat dilihat dari dua sisi, yaitu sisi amal ibadah dan dari sisi organisasi atau perkumpulan. Tarekat yang berkaitan dengan keberadaan Debus adalah tarekat dari sisi organisasi yang berarti sekumpulan salik yaitu orang yang melakukan suluk atau latihan kejiwaan, yang menjalani latihan kerohanian tertentu dengan tujuan mencapai tingkat tertentu yang dibimbing oleh seorang guru. Kata tarekat berasal dari bahasa Arab, yaitu thariqah yang berarti 'jalan', atau 'cara'. Tarekat ini sebenarnya mengacu kepada sistem latihan meditasi maupun amalan (dzikir, wirid) yang dihubungkan dengan banyak sufi, dan organisasi yang tumbuh di seputar metode sufi yang khas. Tujuan dari tarekat ini adalah mempertebal iman dalam hati pengikut-pengikutnya (Nasution, 1995: 128).

Sementara itu di Indonesia terdapat dua aliran Debus yang terkenal, masingmasing berasal dari aliran tarekat Qadiriyah, yaitu tarekat yang dinisbatkan pendirinya Abdul Qadir al Jailani, dan Rifaiyah, yaitu aliran yang didirikan Muhammad ar Rifa'i seorang tokoh sufi besar yang hidup sejaman dengan Syekh Abdul Qadir al-Jailani (Nasution, 1995: 53). Tarekat Rifaiyah didirikan di Irak, tepatnya di Qaryah Hasan dekat Kota Basrah pada abad ke-6 Hijriah atau 1106 Masehi. Tarekat Rifaiyah terkenal dengan amalannya berupa penyiksaan diri dengan melukai bagian-bagian badan dengan senjata tajam diiringi oleh zikir-zikir tertentu. Apabila ada yang luka, gurunya akan menyembuhkan luka itu dengan air 
liurnya sambil menyebut nama pendiri tarekat. Kedua aliran ini dapat ditemui di daerah-daerah tertentu saja. Aliran tarekat Qadiriyah ditemui di daerah Sumatra Barat dan Banten sedangkan tarekat Rifaiyah dapat ditemui di daerah Aceh, Minangkabau, dan Banten (Muzakki, 1990: 52).

Tarekat lain yang juga dikaitkan dengan Debus adalah tarekat Sammaniyah dalam Debus Banten (Nasution, 1995: 6). Tarekat Sammaniyah didirikan oleh Syeikh Muhammad Samman, biasanya mereka melakukan zikir dengan suara lantang seperti tampak dalam Tari Saman Aceh. Syekh Samman telah dipandang sebagai wali yang selalu dimintai perlindungannya dalam permainan Debus. Di daerah Banten jejak aliran tarekat paling jelas menunjuk pada tarekat Sammaniyah dan Rifaiyah. Kedua aliran tarekat itu tumbuh subur karena asosiasi yang kuat dengan Debus.

Sumber sejarah lainnya menyebutkan, Debus ada hubungannya dengan tarekat Rifaiah yang dibawa oleh Nuruddin Ar-Raniry ke Aceh pada abad ke-16. Tarekat ini berprinsip bahwa ketika seseorang dalam kondisi sedang trance dalam zikirnya ia kerap menghantam berbagai benda tajam ke tubuhnya dan dia tidak akan merasakan apa pun karena dia sedang pada tingkat epiphany, yaitu kegembiraan yang tidak terhingga karena 'bertatap muka' dengan Tuhan. Filosofi yang dapat ditangkap adalah "la haula walaa quwwata illaa billaahil aliyyil adhiim" atau "tiada daya upaya melainkan karena Allah semata". Maksud-nya, jika Allah tidak mengizinkan pisau, golok, parang atau peluru sekalipun melukai tubuh seseorang, maka orang itu tidak akan terluka.

Sebagian besar di Banten, Cirebon dan Priangan, Debus "intinya" merupakan media dakwah dengan menggunakan amalan-amalan al-Hikmah dari ajaran tarekat di daerah masing-masing penyebaran. Tetapi ada juga sebagian yang bermain Debus masih menggunakan amalan jangjawokan (amalan untuk mendapatkan kesaktian), seperti di daerah Ujung Berung Atas, Cilengkrang, yang masih kuat Sunda Wiwitannya (Purnama, 1998: 64).
Atraksi-atraksi kekebalan badan merupakan variasi lain yang ada di pertunjukan Debus, antara lain menusuk perut dengan benda tajam atau tombak, mengiris tubuh sampai terluka maupun tanpa luka, makan bara api, memasukkan jarum yang panjang ke lidah, kulit, pipi sampai tembus dan tidak terluka. Mengiris anggota tubuh sampai terluka dan mengeluarkan darah, tetapi dapat disembuhkan seketika itu juga, menyiram tubuh dengan air keras sampai pakaian yang melekat di badan hancur, mengunyah beling/serpihan kaca, membakar tubuh, dan masih banyak lagi atraksi yang mereka lakukan. Dalam atraksi ini setiap pemain mempunyai syarat-syarat yang berat. Sebelum pentas mereka melakukan ritual-ritual yang diberikan oleh guru mereka. Biasanya dilakukan 1-2 minggu sebelum ritual dilakukan. Selain itu mereka juga dituntut mempunyai iman yang kuat dan harus yakin dengan ajaran Islam. Pantangan bagi pemain Debus adalah tidak boleh minum-minuman keras, main judi, bermain wanita, atau mencuri. Pemain juga harus yakin dan tidak ragu-ragu dalam melaksanakan tindakan tersebut. Pelanggaran yang dilakukan oleh seorang pemain bisa sangat membahayakan jiwa pemain tersebut.

Seni permainan Debus tumbuh dan berkembang di beberapa tempat di Kabupaten Serang, terutama di Cikande, Ciruas, Cikeusal, dan Baros. Dulu sebelum Kecamatan Walantaka masuk ke wilayah Kota Serang, Walantaka merupakan tempat primadona seni Debus di Kabupaten Serang. Ternyata di beberapa tempat di Kabupaten Serang seni Debus ini memiliki perbedaan antara satu tempat dengan tempat lainnya meskipun tidak mencolok. Debus Cikande berbeda dengan Debus Walantaka atau Ciruas. Perbedaan kecil itu misalnya dalam pertunjukan Debus Walantaka, sebelum pertunjukan dimulai mereka terlebih dahulu melakukan ritual magis. Para pemain Debus terlebih dahulu bersalaman dengan pemimpinnya yang disebut Syekh Debus, kemudian memi- 
num seteguk air yang sudah diberkahi melalui mantra. Debus Ciruas agak berbeda ketika memulai pertunjukannya. Di saat permainan mulai berjalan, Syekh Debus akan nampak acuh tak acuh seakan tidak perduli kepada pemainnya. Ia hanya duduk di atas tikar dengan memalingkan wajahnya dari para pemain seakan-akan permainan tersebut tidak menarik, padahal ia sedang membaca mantramantra. Hal yang berbeda juga terjadi pada Debus Cikande. Syekh Debus Cikande akan melakukan ritual sekitar 50 menit. Terlebih dahulu ia akan membedaki paku debus, memukulnya, lalu meletakkan bunga kamboja di antara rantai kecil dan hulu kayu Debus.

\section{Perkembangan Kesenian Debus}

Pada abad ke-19, sangat disayangkan seni permainan Debus di Banten sudah hampir punah, kesenian ini hanya bisa ditemukan di desa-desa pedalaman yang penduduknya sangat kuat menganut agama Islam. Namun demikian usaha untuk pengembangan sekaligus pengenalan ke dunia luar terus dilakukan oleh berbagai pihak, sehingga seni ini sekarang sudah dapat berkem-bang dan dilestarikan.

Dalam perkembangannya, Debus hanya dimiliki oleh sekumpulan orang Banten yang tergabung dalam suatu perkumpulan keagamaan, yaitu Tarekat Qadiriyah dan Tarekat Rifaiyah. Keha-diran dan perkembangan kedua tarekat ini berhubungan dengan muncul-nya fenomena Debus di daerah Banten. Dalam hubungan itu tampak bahwa Debus dan tarekat merupakan dua hal yang saling berkaitan (Nasution, 1995: iv).

Dalam perkembangannya, Debus mengalami beberapa perubahan dan penyesuaian dengan lingkungan tempat persebarannya. Pada awalnya keahlian Debus dianggap sebagai produk atau pengaruh agama, perkembangan selanjutnya Debus adalah sebuah seni pertunjukan. Keahlian kekebalan terhadap senjata tidak lagi dijadikan sebagai alat berperang, namun mengalami pergeseran menjadi media untuk hiburan. Keahlian seni permainan ini, sekarang menjadi tontonan untuk menghibur. Debus sudah menjadi jenis seni permainan yang dapat dikategorikan sebagai bentuk seni hiburan dan seni kelompok. Seni permainan tradisional ini sekarang memiliki rombongan yang siap melakukan pagelaran tidak hanya di dalam negeri namun juga di luar negeri.

Beberapa perubahan dari seni Debus di antaranya, pada awal munculnya, pertunjukan Debus hanya diiringi terebang gede, yaitu alat musik berbentuk rebana, sekarang kesenian Debus sudah dilengkapi dengan waditra atau tabuhan pengiring tarian, pencak silat gaya Banten, dan seni suara (dzikir). Banyaknya waditra yang digunakan dalam Debus terdiri atas lima macam, yaitu gendang, kulanter, terebang, tingtit atau dogdog kecil, dan kecrek.

Keahlian Debus pun pada awalnya diturunkan secara turun-temurun dari generasi ke generasi sehingga mereka tidak mengetahui siapa yang pertama mengajarkan ilmu tersebut atau penciptanya. Seni permainan ini dari hari ke hari terus berkembang. Selanjutnya penurunan keahlian yang tadinya hanya berjalan secara pewarisan dari orang tua, saat ini keahlian tersebut dapat diterima dengan cara menjadi murid atau pemain Debus. Status sosial pimpinan Debus sekarang lebih dikenal dengan seseorang yang bergerak di bidang kesenian tradisional Debus Banten atau tokoh masyarakat. Hal ini tentu berbeda dengan kepemimpinan Debus sebelumnya yang dipegang oleh tokoh agama atau kiai. Saat ini kiai tidak lagi menjadi pemimpin Debus, tetapi berada di luar Debus. Kiai berkedudukan sebagai tokoh agama yang dihormati dan disegani oleh anggotaanggota Debus, karena kiai memberikan legitimasi bagi Debus sebagai suatu seni bernafaskan Islam dan tidak bertentangan dengan Islam.

Perubahan kepemimpinan ini memberikan dampak tersendiri bagi masyarakat dalam memandang peranan dan kedudukan Debus. Masyarakat memandang Debus tidak lagi sebagai suatu permainan ritual dan syiar Islam yang dilakukan oleh kiai dan murid- 
muridnya, tetapi sebagai pertunjukan yang bersifat hiburan yang berkaitan dengan Islam dan dilakukan oleh anggota Debus.

Perkembangan selanjutnya dari seni Debus adalah adanya beberapa pemain Debus perempuan. Sebelumnya tidak ada pemain perempuan, dengan pertimbangan seni permainan Debus menuntut adanya kekuatan, dan percaya diri yang tinggi. Seni Debus juga diupayakan menjadi suatu bagian dari adat istiadat yang menjadi lambang identitas dari masyarakat Banten, juga menjadi suatu tontonan rakyat yang bersifat menghibur, komersial, serta dikenal sebagai suatu bentuk permainan kekebalan yang banyak digemari masyarakat. Rentang waktu yang panjang dan Debus tetap ada sampai kini memperlihatkan bahwa Debus mampu bertahan.

Kini sejalan dengan program sadar wisata dengan sapta pesonanya, kesenian Debus akan menjadi salah satu atraksi menarik bagi wisatawan yang berkunjung ke Banten. Saat ini hotel berbintang yang ada di sepanjang pantai Selat Sunda diwajibkan mementaskan kesenian ini, minimal sebulan sekali.

\section{Teknik Penyajian Kesenian Debus}

Debus sebenarnya adalah nama sebuah alat yang terbuat dari besi sepanjang $40 \mathrm{~cm}$ dengan ujung yang runcing. Pada pangkalnya diberi alas (dudukan) dari kayu yang diperkuat dengan lilitan pelat baja, agar tidak cepat terbelah jika dipukul. Di dalam permainan besi itu ditusukkan ke bagian-bagian tubuh, bahkan dipalu bagian pangkalnya, agar bisa menembus bagian-bagian tubuh yang ditusuk. Anehnya, walaupun tubuhnya tertembus alat itu pemain tidak merasa sakit dan tidak mengalami cedera, padahal dialaminya dalam keadaan sadar.

Permainan Debus adalah suatu bentuk permainan rakyat yang tumbuh dan berkembang di Kabupaten Serang, tersebar khususnya di empat kecamatan, ialah Kecamatan Walantaka, Cikande, Ciruas,
Baros, dan di Kecamatan Cikeusal. Tetapi pada saat ini setelah terjadi pemekaran wilayah Kecamatan Walantaka masuk ke dalam wilayah Kota Serang.

Beberapa unsur yang ada dalam Debus adalah permainan, peralatan, pemimpin (syekh) dan anggota, pertunjukan Debus, dan musik pengiring. Unsur lainnya adalah busana, tempat, dan waktu pertunjukan. Unsur-unsur tersebut merupakan kesatuan yang memperlancar pelaksanaan pertunjukan Debus.

\section{a. Syarat-syarat untuk Menjadi Pemain}

Unsur pemimpin dan pemain atau anggota dalam Debus merupakan unsur penting dalam struktur keanggotaan. Setiap tim Debus mempunyai pemimpin yang disebut Syekh Debus. Pada masa itu Syekh Debus adalah pimpinan tarekat di kampungnya. Ia menjadi motivator bagi pemain dalam ritual permainan Debus. Seorang pemimpin perkumpulan Debus adalah seorang yang dikenal sebagai seorang sepuh yang dituakan. Ia memiliki tingkat ilmu Debus yang lebih mumpuni dari para anggotanya, sehingga ketua Debus memiliki karismatik. Ia yang mengorganisir seluruh kegiatan kelompoknya menentukan anggota yang terlibat dalam suatu aktraksi dan turut berperan dalam menyukseskan suatu acara. Pemimpin juga berperan penting dalam seluruh acara pertunjukan mulai dari tahap persiapan, pelaksanaan acara sampai selesai. Dalam tahap persiapan pemimpin berupaya memberikan perlindungan dan keselamatan magis kepada para anggotanya yang menjadi pemain Debus dengan melakukan kegiatan ritual di malam hari sebelum pertunjukan dilaksanakan. Saat pelaksanaan acara, ketua juga memberikan perlindungan dari kecelakaan yang terjadi selama pertunjukan.

Unsur anggota terbagi menjadi dua kategori keanggotaan, yaitu anggota permainan Debus dan anggota Debus. Anggota permainan Debus adalah anggota yang khusus bermain Debus dan terlibat dalam ritual permainan Debus. Mereka yang tidak terlibat dalam ritual permainan Debus adalah mereka yang hanya belajar ilmu Debus. Anggota Debus ini lebih mengkhususkan kepada belajar ilmu Debusnya daripada untuk seninya. Anggota permainan 
Debus dibagi lagi menjadi dua kategori keanggotaan, yaitu anggota yang khusus bermain Debus (pemain Debus), dan anggota yang khusus memegang alat musik (pemusik). Pemain Debus sebagian besar adalah orang kampung yang hidup sederhana dari bertani dan berdagang. Biasanya para pemain adalah anggota tarekat dan menjalankan sejumlah pantangan yang dilarang dalam agama Islam (Nasution, 1995: 43).

Syarat-syarat untuk menjadi pemain Debus antara lain:

a. Umur sepuluh tahun sampai lima puluh tahun, laki-laki dan perempuan, dan beragama Islam.

b. Mereka dididik/dilatih oleh pelatih utama.

c. Latihan silat/latihan membaca wirid sambil berpuasa antara tujuh sampai empat puluh hari.

Para pemain tidak boleh sombong, tidak boleh ingin dipuji dan harus selalu rendah hati. Kalau bertabiat sombong, senjata tajam dan api akan mempan kepada tubuhnya, sedangkan kalau mereka selalu rendah hati dan beriman kepada Allah, senjata tajam dan api tidak akan mempan pada tubuhnya. Dalam setiap permainan Debus selalu dihadirkan (Sunda: nyambat) Sultanul Aulia Syekh Abdul Qodir al Jaelani. Wirid hanya untuk daya tarik bagi penonton.

Banyaknya pemain kesenian tradisional Debus antara 12 sampai 15 orang, yang berfungsi sebagai berikut:

a. 1 orang juru gendang,

b. 1 orang penabuh rebana besar,

c. 2 orang penabuh tingtit atau dogdog,

d. 1 orang penabuh kecrek,

e. 4 orang yang mengumandangkan zikir,

f. 5 orang pelaku atau pemain yang mempertunjukkan kekebalan orang,

g. 1 orang Syekh (dalang) merangkap pelaku atau pemain

\section{b. Waditra yang Dipergunakan}

Dalam permainan Debus terdapat unsur musik berupa suara yang muncul dari alat musik dan nyanyian yang dilagukan oleh para pemain dan pemusik. Nyanyian itu merupakan pernyataan keyakinan dengan melantunkan ayat dalam kitab suci al-Quran.

Banyaknya waditra yang dipergunakan pada permainan Debus ada 5 macam, ialah:

a. Sebuah gendang tanggung, dapat ditambah tiga atau empat buah lagi yang berfungsi sebagai pengiring gerak tari.

b. Dua buah kulanter (gendang kecil) merupakan pelengkap bagi gendang tanggung.

c. Sebuah terbang atau rebana besar yang berfungsi sebagai gong. Dua buah tingtit atau dogdog kecil yang berfungsi sebagai pengisi kekosongan.

d. Tiga buah kecrek, berfungsi sebagai pengatur irama, untuk memantapkan gerakan pemain.

Gendang yang digunakan adalah gendang tanggung, lebih kecil dari gendang degung, dan sedikit lebih besar dari gendang kulanter. Ukuran gendang tanggung: garis tengah bagian depan $25 \mathrm{~cm}$, garis tengah bagian belakang $15 \mathrm{~cm}$, dan panjangnya $50 \mathrm{~cm}$. Kulanter sama seperti layaknya kulanter pada gamelan degung. Terbang atau rebana besar terbuat dari kayu dan kulit kerbau dengan garis tengah bagian depan $60 \mathrm{~cm}$, garis tengah bagian belakang $40 \mathrm{~cm}$, dan tebalnya $25 \mathrm{~cm}$. Tingtit atau dogdog kecil terbuat dari kayu dan kulit kerbau, sama seperti dogdog pada reog, garis tengah bagian depan $15 \mathrm{~cm}$, garis tengah bagian belakang $10 \mathrm{~cm}$, dan panjangnya $25 \mathrm{~cm}$. Kecrek terbuat dari logam atau perunggu tipis, garis tengahnya $15 \mathrm{~cm}$ dan tebalnya $0,3 \mathrm{~cm}$

\section{c. Busana yang dipakai}

Busana yang dipakai oleh rombongan permainan Debus tidak dibedakan antara busana pemain, penabuh, pezikir maupun syekh. Semuanya memakai seragam, yaitu baju kampret dan celana pangsi. Warna pakaian tidak ada ketentuan yang menetapkan warna tertentu, tetapi pada umumnya berwarna gelap. Semua pemain mengenakan ikat kepala 
yang disebut lomar atau iket terbuat dari kain batik berbentuk segi tiga.

\section{d. Lagu-lagu Pengiring Pertunjukan}

Lagu-lagu yang dikumandangkan semuanya menggunakan kata-kata dalam bahasa Arab, bernafaskan keagamaan, berisi pujian atau pujaan kepada keagungan Allah SWT, dan pujian kepada Nabi Muhammad SAW. Lagu-lagu yang dikumandangkan sampai sekarang tidak terpengaruh oleh lagu Sunda, Indonesia atau lainnya. Lagu-lagu itu dinyanyikan dengan gaya berzikir dan gaya beluk (dengan suara melengking tinggi). Lagu tersebut biasanya berbentuk salawat.

\section{e. Jalannya Permainan atau Pertunjukan} sebagai berikut: Jalannya pertunjukan Debus adalah

1. Gemberung: merupakan pembukaan atau awal pertunjukan. Waditra dipukul bergantian selama 2-3 menit.

2. Zikir: pezikir menyanyikan lagu dzikir yang isinya memuji kebesaran Allah SWT. dan salawat kepada Nabi Muhammad SAW. serta para sahabatnya, diiringi tabuh-tabuhan.

3. Beluk: beluk adalah jenis lagu yang dinyanyikan dengan suara nyaring dan tinggi, bersahut-sahutan, juga di iringi bertabuhan.

4. Silat: ketika beluk sedang dinyanyikan maka keluar seorang pesilat (gaya Banten) yang mendemonstrasikan tarian silat, lalu keluar seorang lagi. Keduanya terlibat dalam perkelahian, dan berakhir dengan bersalaman tak ada yang kalah atau menang.

5. Tusuk menusuk dengan gada debus: dua orang mempertunjukkan tari silat lalu saling menusuk dan saling memukul dengan gada Debus, sasaran tusukan adalah seluruh bagian tubuh dilakukan secara bergantian, sampai pertunjukan berakhir.

6. Mengupas kelapa: sebutir kelapa yang utuh bersabut dikupas dengan menggunakan kekuatan gigi. Setelah sabutnya habis, kelapa itu lalu di pecahkan dengan jalan memukulkan kelapa itu di atas kelapa. Kemudian kelapa dimakan berikut tempurungnya sampai habis.

7. Mengiris tubuh atau anggota tubuh, diiris-iris dengan pisau yang sangat tajam sehingga mengeluarkan darah. Kemudian luka itu dibasuh dengan air maka lukanya sembuh lagi seperti sedia kala. Lalu menggunakan golok tajam untuk membacok tubuh, tapi tidak menimbulkan cedera, padahal dilakukan secara sadar (tidak hilang ingatan).

8. Mengerat lidah: pemain menjulurkan lidah lalu mengeratnya, dan lidah berdarah, tetapi lidah itu segera sembuh kembali.

9. Tangga golok: sebuah tangga yang anakanak tangganya berupa golok-golok yang sangat tajam. Seorang pemain menaiki anak tangga dengan kaki telanjang, kemudian pemain itu duduk di puncak anak tangga, sambil merokok.

10.Memakan kaca: atraksi selanjutnya ialah pemain memakan kaca, baik berupa kaca yang biasa dipasang pada jendela rumah, gelas, bola lampu, dan sebagainya. Perbuatan serupa itu tidak menimbulkan luka pada mulut atau pun lidah.

11. Menggoreng telur di atas kepala: pemain menggoreng telur di atas kepala pemain lainnya. Api dibiarkan menyala pada rambut lalu kuali yang sudah diberi minyak kelapa ditaruh di atasnya, dan digunakan untuk menggoreng telur atau kerupuk hingga matang. Akan tetapi rambut dan kulit kepala pemain itu tidak mengalami luka bakar atau cedera.

12. Menyiram tubuh dengan air keras: tubuh pemain disiram dengan air keras, sampai hancur dan berjatuhan ke tanah, namun kulit tubuhnya tidak mengalami luka bakar. Air keras itu pun digunakan mencuci anggota tubuh.

13. Membakar tubuh: dua orang pemain memainkan api, lalu digunakan untuk menyisir rambut dan membakar tubuh lawannya, tetapi tidak mengalami cidera semua itu dilakukan dalam keadaan sadar.

Keahlian untuk menguasai semua permainan Debus tidak diperoleh dengan mudah. Setiap penguasaan satu jenis permainan harus melalui suatu proses ritual 
tertentu yang cukup lama, misalnya 40 hari atau 100 hari tergantung ketentuan ketua. Ritual merupakan salah satu unsur utama dalam Debus. Ada dua jenis upacara atau ritual, yaitu ritual debus dan ritual permainan debus. Ritual Debus adalah suatu proses upacara ketika seseorang menjadi anggota Debus. Ritual permainan debus adalah suatu proses upacara menjelang permainan Debus. Biasanya dilakukan dalam suatu kegiatan yang berkaitan dengan acara keagamaan, khitanan, acara kenegaraan atau acara komersial untuk pertunjukan pada wisatawan.

\section{f. Tempat Pertunjukan}

Tempat pertunjukan Debus terbagi menjadi dua bagian yaitu:

a. Tempat wiyaga atau tempat para pemukul tabuhan pengiring, bisa berupa panggung, di lantai atau di bagian mana saja.

b. Tempat Atraksi: tempat arena atraksi berada di hadapan para wiyaga, ukurannya minimal 6 × 6 meter persegi, tidak bergoyang bila atraksi dilakukan dan tidak licin, bisa juga di lantai.

\section{g. Waktu Pertunjukan}

Umumnya pertunjukan Debus diadakan setelah sholat Magrib, yaitu sekitar pukul 7 malam. Tetapi jika perlu waktu ini dapat menyimpang dari kebiasaan bisa kapan saja, siang hari, malam hari, pagi atau sore hari, tergantung permintaan yang mengundang kesenian ini.

\section{h. Lama Pertunjukan}

Lama pertunjukan berlangsung antara 80 menit sampai 105 menit.

\section{i. Penonton}

Pertunjukan Debus dilaksanakan di tempat terbuka atau tertutup. Penonton bisa mengambil tempat di sekitar pertunjukan; di muka, di belakang; atau di samping, dengan jarak yang cukup. Jangan sampai terkena cipratan barang berbahaya seperti api atau air keras.

\section{PENUTUP}

Dari uraian di atas dapat disimpulkan bahwa sejarah kesenian Debus di Kabupaten Serang dapat dikatakan masih gelap karena tidak adanya sumber-sumber tertulis yang bisa menjelaskan atau mengungkapkan periode Debus sebelum abad ke-19. Periode ini merupakan periode yang panjang dalam perjalanan sejarah Debus Banten. Periode yang cukup gelap, karena belum dijumpai berita tertulis tentang Debus Banten pada masa itu. Sumber sejarah lokal seperti "Babad Banten" tidak menyinggung keberadaan Debus ini dalam uraiannya. Tidak adanya sumber lokal tertulis mengenai Debus sebenarnya bisa dipahami, mungkin saja hal tersebut merupakan rahasia perkumpulan Debus ini sehingga sukar untuk menelusuri sejarah Debus secara jelas. Biasanya sejarah dan materi Debus hanya diketahui oleh anggota dan keluarga.

Dalam periode yang panjang tersebut, Debus belum memiliki identitas sebagai suatu bentuk kelompok seni. Debus hanya dikenal sebagai suatu permainan kekebalan yang berkaitan dengan tarekat. Bahkan mungkin saja kata Debus pun belum dikenal, karena permainan ini lebih dikenal dengan nama alatnya, yaitu al-Madad.

Berdasarkan sejarahnya, budaya Debus berkaitan erat dengan penyebaran agama Islam di Indonesia. Pada masa Penembahan Maulana Hasanuddin (15321570), Debus digunakan sebagai seni untuk memikat masyarakat Banten yang masih memeluk agama Hindu dan Budha dalam rangka penyebaran Agama Islam. Menurut tradisi lisan, Debus dikembangkan untuk menarik masyarakat Banten agar masuk dan memeluk agama Islam. Pertunjukan Debus saat itu biasanya digelar di dalam sebuah bangunan tiyamah dekat Masjid Agung Banten. Saat itulah bagi siapa pun yang ingin menyaksikan pertunjukan syaratnya adalah membaca dua kalimah syahadat. Kemudian pada masa pemerintahan Sultan Ageng Tirtayasa abad ke-17 (1651-1652), Debus difokuskan sebagai alat untuk membangkitkan semangat para pejuang dalam melawan penjajah Belanda. Oleh karena itu Debus merupakan kesenian beladiri guna memupuk rasa percaya diri. 
Periode yang mulai terang adalah ketika masa mendekati awal kemerdekaan. Sekitar tahun 1938 berdiri perkumpulan Debus di Kabupaten Serang, tepatnya di Kecamatan Walantaka, dipimpin oleh seorang kiai besar bernama Haji Ismail dengan 6 orang anggota lainnya yaitu: Haji Sapawi, H. Tahir, H. Nawawi, H. Balqi, wak Kasad, dan Kiai Abdul Rasyid. Setelah pimpinannya meninggal dunia, bersamaan dengan penyerahan Kedaulatan RI ke Belanda atau hijrah ke Yogyakarta, Debus diserahkan kepada Residen Banten K.H. Achmad Khatib. Sejak itu peralatan Debus yang asli berada di suatu bangunan di Keresidenan Banten.

Kini sejalan dengan program sadar wisata dengan sapta pesonanya, kesenian Debus akan menjadi salah satu atraksi menarik bagi wisatawan yang berkunjung ke Banten. Saat ini hotel berbintang yang ada di sepanjang pantai Selat Sunda diwajibkan mementaskan kesenian ini, minimal sebulan sekali.

\section{DAFTAR SUMBER}

1.Buku

Atmadibrata, Enoch et al. 2006.

Hasanah Seni Pertunjukan Jawa Barat. Bandung: Dinas Kebudayaan dan Pariwisata Jawa Barat.

Atjeh, Abu Bakar. 1993.

Pengantar Ilmu Tarekat. Solo:

Ramadani. 1994.

Pengantar Sejarah Sufi dan Tasawuf. Solo: Ramadani.

Dinas Pendidikan. 2003.

Profil Seni Budaya Banten. Bandung:

Disdik Provinsi Banten.

Disbudpar Provinsi Banten. 2008.

Data Kebudayaan Banten. Banten:

Disbudpar.

Disbudparpora Kabupaten Banten. 2009.
Buku Khasanah Seni Tradisional

Kabupaten Serang. Banten:

Disporabudpar Kab. Serang.

Djajadiningrat, R. Husein. 1982.

Tinjauan Kritis Sejarah Banten.

Jakarta: Djambatan.

Fadillah, Moh Ali. 2004.

"Kesenian Debus dari Perspektif

Sejarah Banten”, Jurnal Kebudayaan

dan Pariwisata, Vol. VIII, Jakarta:

Puslitbang Kebudayaan dan Pariwisata,

Depbudpar.

Pusat Bahasa. 2008.

Kamus Besar Bahasa Indonesia.

Jakarta: Gramedia Pustaka Utama

Kartodirdjo. 1984.

Pemberontakan Petani Banten. Jakarta:

Pustaka Jaya.

Lubis, Nina H. 2003.

Banten Dalam Pergumulan Sejarah.

Jakarta: LP3ES.

Masduki, Aam, et al. 2005.

Kesenian Tradisional Provinsi Banten, Bandung: BKSNT Bandung.

Michrob, Halwany dan A. Mudjahid H. 1993

Catatan Masa Lalu Banten. Serang:

Saudara.

Muzakki, Makmun. 1990.

Tarekat dan Debus Rifaiyah di Banten. Skripsi Sarjana Fakultas Sastra UI,

Depok: UI.

Nasution Isman Pratama. 1995.

Debus, Islam dan Kiai, Studi kasus di

Desa Tegalsari, Kecamatan Walantaka,

Kabupaten Serang. Tesis, Jakarta: UI.

Purnama, Yuzar. 1998.

Debus, Bisakah Menjadi Pertunjukan

Eksklusif, dalam Buddhiracana Vol II,

No. 6, Mei 1998, Bandung: BPSNT.

Sariyun, Yugo, et al. 1991. 
Nilai Budaya Dalam Permainan

Rakyat. Bandung: Depdikbud.

Seksi Kebudayaan. 1990.

Kesenian Tradisional Kabupaten

Serang. Serang: Depdikbud.

Tim Penyusun Subdin Kebudayaan. 2003.

Profil Seni Budaya Banten. Serang:

Disdik Provinsi Banten.

2. Internet

http://menembuslangit.blogspot.com http://wwwsahabatsilat.com

http://wwwbanten.go.id

http://wwwsuarapembaharuan.com/

news/2004/10/31/index.htm

3. Wawancara

1. Beni Kusnandar, Serang, 27 Maret 2011

2. Suha, Baros, 28 Maret 2011

3. Mamat, Baros, 28 maret 2011 